Safeguarding, its Genealogy and Governance.

Two Essays on UNESCO's

Convention for the Safeguarding of Intangible Cultural Heritage

\title{
Safeguarding.
}

\section{A key dispositif of UNESCO's \\ Convention for the Safeguarding of Intangible Cultural Heritage}

\author{
Antonio Arantes ${ }^{7}$
}

' Universidade Estadual de Campinas, Departamento de Antropologia, Campinas/SP, Brasil

\begin{abstract}
The expression 'safeguarding intangible cultural heritage' was formed within the context of transformations in the instruments and strategies for protecting cultural elements usually designated 'folklore and traditional (and popular) culture.' The adoption of a 'cultural heritage approach' to this subject was a somewhat turbulent process that drew, since the mid-twentieth century, a winding path of dialogues with, and divergences from, common sense notions and mainstream preservationist culture. Throughout this process, political and conceptual possibilities for social engineering were envisaged, some were discarded, choices were legitimized and, no less importantly, networks were formed of agents and narrators of the political and legal negotiations that eventually lead to designing UNESCO ICH Convention as officially adopted. This path will be explored in the following comments on the formation of safeguarding as a cultural heritage policy dispositive $e^{2}$ and significant contrasts to other instruments, in relation to which it has acquired specificity, meaning and scope. Key words: Unesco; Convention for the Safeguarding of Intangible Cultural Heritage; safeguarding; cultural heritage dispositifs; intellectual ethnography.
\end{abstract}

This wording follows the Recommendation on the Safeguarding of Traditional Culture and Folklore, adopted by the UNESCO General Conference, 15 November 1989, hereinafter the 1989 Recommendation.

2 I follow the definition as provided in Michel Foucault (1977), hereafter 'Le jeu de Foucault'. 


\section{Salvaguarda.}

\section{Um dispositivo-chave da Convenção da UNESCO para a Salvaguarda do Patrimônio Cultural Intangível}

\section{Resumo}

A expressão 'salvaguarda do patrimônio cultural imaterial' constituiu-se em meio a transformações dos instrumentos e estratégias de proteção de elementos culturais que vinham sendo denominados 'folclore e cultura tradicional (e popular)'. A adoção de uma 'abordagem patrimonial' para esses temas foi um processo razoavelmente turbulento, que desenhou, desde meados do século XX, um caminho tortuoso de diálogos e divergências em relação a noções do senso comum e à cultura preservacionista dominante. Ao longo desse processo, possibilidades conceituais e políticas de 'engenharia social' foram vislumbradas, algumas foram descartadas, legitimaram-se escolhas e, não menos importante, formaram-se redes de agentes e narradores das negociações políticas e jurídicas que conduziriam finalmente à concepção da Convenção da Unesco do Patrimônio Cultural Intangível adotada oficialmente. Essa trilha será examinada nos comentários que seguem sobre a 'salvaguarda' enquanto dispositivo de políticas patrimoniais e seus contrastes com outros instrumentos em relação aos quais ganha especificidade, significado e amplitude.

Palavras-chave: Unesco; Convenção para a Salvaguarda do patrimônio imaterial; salvaguarda; dispositivos de normativas patrimoniais; etnografia intelectual. 


\title{
Safeguarding.
}

\section{A key dispositif of UNESCO's \\ Convention for the Safeguarding of Intangible Cultural Heritage}

\author{
Antonio Arantes
}

\section{Subject and framing}

My framing of this theme requires rethinking notions such as 'metaculture' and 'heritage regime' that today pervade discussions of heritage (Kirchenblatt-Ginblett 2004; Bendix et al. 2012), but which I use here with specific meanings. I begin with the concept of metaculture, inspired by the distinction first formulated by Roman Jakobson between language object and metalanguage. For the linguist, metalanguage is a dimension of everyday communication that can be termed reflexive since it performs a 'gloss' function (Jakobson 1963). Analogously, in the case of cultural heritage, preservation can be conceived to perform a metalinguistic function in relation to its 'culture object.'

Cultures, similarly to languages, are observable through the overall variations in their occurrences, the latter being indissociable from the agents who realize them and the circumstances of their realization. Even those that are more specialized or less socially disseminated seldom occur in a single version. What we find are sets of variants of phenomena of the same kind, produced by diverse social agents. Furthermore, practices are not dissociated from one another but integrated in systems (Arantes 2009). Thus, by selecting one of these variants - or even a set of them - as an object of safeguarding, following the principles of 'authoritative heritage discourse ${ }^{3}$ proper to each regime, processes are set in motion that will predictably provoke effects and repercussions on the system of which they are part. By being transformed into metaculture, the version or variant object will acquire specific values and connotations that potentially transform it into an ideal version of the real, so to speak, exemplary in the double sense of the word: as illustration and model. In the case of built heritage, we can recall the example of palaces and cathedrals, more resplendent perhaps than they ever were in the past, alongside temples and manor houses not encompassed by the authoritative parameters and thus not afforded such prominence. In the case of intangible elements, we can consider choreographies never before executed with such precision, perhaps, or with such eye-catching costumes, alongside performances of the same kind realized in everyday clothing.

Preservation has been guided by social history, architecture, archaeology, geography, law and, more recently, anthropology. These are some of the areas of knowledge that support the preparation of dossiers - legal documents that identify, delimit, legally institute and regulate the management of what is being preserved. Such modes of knowledge form the basis for defining the norms that end up guiding the trajectory - or biography ${ }^{4}$ of preserved items, following their inclusion on register lists or books, and the authoritative heritage discourse, legitimized by erudite knowledge and implemented by heritage institutions.

\footnotetext{
3 Cf. Laurajane Smith (2006). I prefer to reinterpret the formula by using the expression 'authoritative heritage discourse' since this expression, differently from Smith's, does not dissociate agent from agency, or an argument of authority from whoever gave authorization to its utterance. Some heritage discourse can be authorized by a third party, but do not necessarily express what is institutionally correct and acceptable; 'authoritative' inherently expresses the authority of the argument itself.

4 See argument about 'trajectory of commodities' and 'politics of value' in Appadurai (1986)
} 
From this viewpoint, the construction of heritage realized by preservation in general, and 'safeguarding' in particular, should not be confused with culture on the ground, with life as it really is, so to speak. Instead it can be considered a second-level construction, culture about culture, irrespective of whether the latter is indigenous, aboriginal, popular, erudite or other, produced in the interaction of the various social agents involved (local and institutional), that creatively amalgamate and embed it in social life, old and new, flavoured with renewed senses of tradition and authenticity. ${ }^{5}$

This line of reasoning suggests that the actions catalysed by preservation, given that they are not merely reiterative but inaugurate qualified meta-realities, can produce reflexive and potentially dislocating effects that alter the values that ordinarily constitute the culture object. Here I am not making value judgments but underlining the fact that, by seeking to strengthen cultural elements, preservation can add socio-political agendas and symbolic meanings to them, associated with new guises that magnify their public presence. Formulated in more generic terms, the contiguity between this metaculture, framed by the seal of heritage and highlighted by official promotion, and the reference culture, hostage to the (mis)fortunes of its everyday context, probably has effects on the values attributed to both. But while the proximity valorises both, it does so in opposite senses, tending to draw attention to what is interpreted as a support to an 'outstanding universal value' (in the case of material items) or to what was 'curated' as a prime example of the safeguarded ICH - in both cases, the instances that best correspond to the preservation norm. As a consequence, the hypothesis that should orient the interpretation of scholars and occupy the attention of preservation agencies is that this contiguity can erode the legitimacy and symbolic efficacy of the culture object, which remains subject to the vicissitudes of the everyday, and, in terms of the social condition of its agents, to their political power and capacity to negotiate in customary social exchanges. ${ }^{6}$ By performing a metacultural function, therefore, the registered standard can acquire the sense of a highbrow form and become a criterion for the aesthetic evaluation of the actual performance. It is under this new condition, as a metacultural reality, that the preserved cultural element - whether tangible or intangible -maintains reflexive relations with social practices on the ground and with the ways of life on which its continuity and resignification depend.

One consequence of this argument is that the juxtaposition enabled by safeguarding makes evident differences between life and heritage as representation. It might be said that the latter questions and dislocates its referent - the culture object - through its endorsement by the seal of official preservation. Under this new condition, tangible and intangible heritage affects the legitimacy of the elements to which they refer - both positively and negatively - as well as the meanings of continuity and belonging associated with them by their agents, i.e., communities, group or individuals (hereafter CGIs). Certainly, heritage cannot be considered simply an 'inheritance': it becomes a 'bridge' technically constructed towards the future, "by knowledge produced by whoever 'encountered' the [reference] objects of the past" (Davalon 2015). Consequently, it becomes an ethical responsibility of the preservation agents to mitigate the negative effects of their policies on the wider context in which safeguarding actions are implemented.

I turn now to the notion of heritage regime, which I associate with the Foucauldian concept of dispositif (Foucault 1977) highlighting two aspects of directly relevance to the subject of my remarks. The first is that the concept articulates both discursive and non-discursive aspects of its object. In the philosopher's words:

\footnotetext{
See the argument about 'invention, 'convention' and the importance of 'creativity' in Wagner (1975).

6 It is worth clarifying that here I am referring generically to situations frequent in ICH safeguarding processes in which particular social agents question the criteria adopted by preservation agencies for inclusion in inventories and participation in safeguarding actions, as well as the distribution of the benefits deriving from them. In my view such claims indicate that some interpretations or variants may correspond more than others to the officially registered version. Consequently, performing a metacultural function, the registered pattern may acquire the value of a 'highbrow form' and become the criterion used to appraise other contemporary manifestations.
} 
Ce que j'essaie de repérer sous ce nom, c'est, premièrement, un ensemble résolument hétérogène, comportant des discours, des institutions, des aménagements architecturaux, des décisions réglementaires, des lois, des mesures administratives, des énoncés scientifiques, des propositions philosophiques, morales, philanthropiques, bref : du dit, aussi bien que du non-dit, voilà les éléments du dispositif. Le dispositif lui-même, c'est le réseau qu'on peut établir entre ces éléments (Foucault 1977: 1).7

The second refers to the notion of épistémè, which is associated with the concept of dispositif and proves especially pertinent to these comments. Foucault replies to his interviewer in the cited work with the following explanation:

Si tu veux, l'épistémè, je la définirais, en faisant retour, comme le dispositif stratégique qui permet de trier parmi tous les énoncés possibles ceux qui vont pouvoir être acceptables à l'intérieur, je ne dis pas d'une théorie scientifique, mais d'un champ de scientificité, et dont on pourra dire: celui-ci est vrai ou faux. C'est le dispositif qui permet de séparer, non pas le vrai du faux, mais l'inqualifiable scientifiquement du qualifiable (Foucault 1977:3). ${ }^{8}$

The dispositif acts as an apparatus, a tool, constituting subjects and organizing them. Its political efficacy, Foucault avers, referring to the power of governors and State apparatuses, has "pour condition de possibilité, l'ancrage dans les comportements, les corps, les relations de pouvoir locales, où il ne faudrait pas voir du tout une simple projection du pouvoir central" (Foucault 1977:5). ${ }^{9}$

The regimes simultaneously create and regulate clashes between powers and counter-powers, which take place in the public sphere and are motivated by social demands of diverse kinds, usually political or economic in nature. In the case of heritage, these demands are also academic and professional. All such regimes, like the one instituting the safeguarding of intangible cultural heritage, are products of their time. While in its early days and for half a century after, preservation practices were embedded in elitist culture and values, referenced to artworks, monuments and sites of outstanding universal value, we enter the twenty-first century with democratic political demands and under the aegis of movements campaigning for citizenship rights, based on ethnic and geopolitical differences, in the name of universal values, such as freedom of expression, environmental protection and gender equity. As David Harvey (2001) astutely argued, referring to heritage as a process, this phenomenon forms part of political change, more specifically those relating to citizenship rights, and, if it is to be adequately understood, needs to be contextualized within the dynamic relations between civil society and State - which, in my view, include changes of political regime and to political culture. ${ }^{10}$

Returning the philosopher's reflections, in this dynamic context it becomes especially important to the understanding of 'safeguarding' that, as a dispositif, "tel discours peut apparaître tantôt comme programme d'une institution, tantôt au contraire comme un élément qui permet de justifier et de masquer une pratique qui,

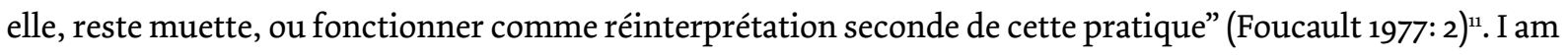
suggesting, therefore, that safeguarding, as a dispositif, triggers an effect of duplicity, 'a second interpretation'

\footnotetext{
7 "What I am attempting to discern by this name is, in the first place, a resolutely heterogeneous ensemble consisting of discourses, institutions, architectural forms, regulatory decisions, laws, administrative measures, scientific statements, philosophical, moral and philanthropic propositions - in short, the said as much as the unsaid, these are the elements of the dispositif. The dispositif itself is the network that one can establish between these elements" (Foucault 1977: 1, free translation).

8 "If you wish, I would define the épistémè (...) as the strategic dispositif that allows the selection from among all possible statements of those that will be acceptable within, I would not say a scientific theory, but a field of scientificity, and of which one can say: that one is true or false. It is the dispositif that allows the separation not of the true from the false, but of what qualifies as science from what does not" (Foucault 1977: 3, free translation).

9 "as a condition of possibility its anchoring in behaviours, bodies, local power relations, which we should avoid seeing as a simple projection of a central power" (Foucault 1977: 5, free translation).

10 Article 216 of the 1988 Brazilian Constitution clearly illustrates this fact. Described as a 'Citizen's Constitution,' it promoted changes to the concept of cultural heritage, defining it no longer in relation to hegemonic historical and aesthetic values, but "to material or immaterial items (...) that bear references to the identity, action, memory of the different groups forming Brazilian society."

11 "it may appear sometimes as a program of an institution, sometimes, on the contrary, as an element that enables the justifying and masking of a practice that itself remains silent, or functions as a second reinterpretation of this practice” (Foucault 1977: 2, free translation).
} 
of its object, dislocating it and presenting itself as a materialization of the highbrow form (the institutional regime). Under this new condition, as 'a second reinterpretation', it can conceal and silence its referent by raising it to the condition of prototype at the level of the everyday, a living example of the regime that applied to it and that, in a new guise, ceases being a metacultural reality and becomes instead a reference point, an expression of life as it came about to be. In these new guises it disputes for visibility - and, who knows, even for legitimacy - with raw experience, the reality lived by social agents from which it originated.

Hence it is up to the managers of safeguarding to mitigate the reflexive effects of the realities in whose creation they participate. These realities can become more attractive and more convincing than the culture object, despite being dependent too on the new conditions of production that the common social agent, the cultural community, does not control and to which this population is submitted insofar as they are controlled by the State and mediated by political ideology, when not by party interests. Consequently, to understand safeguarding not only in the abstract, as I do in my present commentary, but concretely, with regard to their effects on the historicity of heritage (see also Arantes 2009) and on the quality of life of its agents, it is essential to take into account the specific conditions in which it is implemented. This poses problems for managers interested in constructing generic performance indicators for evaluating public policy results in this area.

\section{Mutations to the notion of safeguarding}

As I pointed out at the beginning of these reflections, the notion of safeguarding was born out of the problematics surrounding what in the 1950 s was called 'the defence of folklore.' Folklore and traditional (and popular) culture, encompassing music, arts and crafts, as well as diverse genres of oral expression such as myths, folktales, epic poems, riddles and so on, were collected by institutions and private researchers long before the nineteenth century, when they gradually became reinterpreted as national cultural emblems. ${ }^{12}$ Safeguarding, as envisaged by the ICH Convention (Article 2.1), pertains to objects historically formed through this expressive dimension of culture and cultural policies.

The initial focus of this historical trajectory are music and the diverse manifestations of orality. Some collections, such as the one assembled from 1948 onward by Folkways Records and incorporated into the Smithsonian Institution in 1987, as well as the collection available to researchers at the Maison des Cultures $\mathrm{du}$ Monde, created in $1997,{ }^{13}$ became an international benchmark for the methodologies employed in the identification and documentation of ethnographic material. However, the objective of the ICH treaty is not the register of cultural expressions and the formation of collections per se. Its aims, innovative for their time, were constituted over the course of a process that includes important changes in the conception of the objects of protection, the motives that feed it and the aims of the strategies adopted.

As I understand it, at the start of this process the objective was to conserve the authenticity and the historico-documental value attributed to particular cultural expressions, saving them from undesirable changes provoked by the culture industry and the emerging mass media. By 2000 , when the Convention was being drafted, the continuity of living processes of constructing senses of identity had become the main issue to be resolved. This is the line of inquiry I seek to explore over the following pages.

\footnotetext{
12 Examples include the Pitt Rivers Museum (Oxford, 1884); the Museum of Archaeology and Anthropology (Cambridge, 1884); the Peabody Museum of Archaeology and Ethnology (Harvard University, 1866); and the Musée de l'Homme (Paris, 1937).

13 For further information see <https:||folkways.si.edu/folkways-records/smithsonian>and <http:/|www.maisondesculturesdumonde.org>
} 


\section{A matter of copyright?}

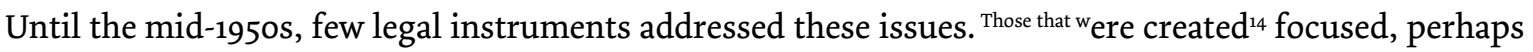
with little practical effectiveness, on protecting the copyright of ' folkloric' ${ }^{15}$ musical expressions in a context that had begun to be dominated by the culture industry and the mass media. Along these lines, it is worth noting that the pioneering demand for the creation of an International instrument for the protection of folklore had first been introduced into the multilateral political sphere by the Bolivian government in 1973. At the request of the Andean country's Ministry of Foreign Affairs and Religion, the Director General of UNESCO submitted the examination of this proposal to the Intergovernmental Copyright Committee, along with "the results of the Committee of Experts Charged with Drafting a Model Law on Copyright for Developing Countries in Africa" ${ }^{16} \mathrm{It}$ was only at the end of the 1970s, however, and the start of the 1980s, just when globalization was taking hold, that UNESCO implemented a number of measures that would eventually develop into what is today defined as ICH safeguarding.

In the next section I briefly examine some of the documents produced over the course of this trajectory, focusing on the main shifts in the strategies formulated to preserve what today falls under the rubric of ICH. I also seek to identify precedents and surrounding issues that, as commonly held views, are also frequently expressed in the demands and arguments of various stakeholders, revealing an entire semantic field that gives life and broader significance to ICH and to related management strategies.

\section{Folk arts}

I begin with a series of questions debated by participants at the Symposium on the elaboration of a Ten-year Plan for the Preservation and Promotion of the Performing Arts and Music in Africa and Asia (hereafter Ten-year Plan), organized by UNESCO in $1977 .{ }^{17}$ This document presents a detailed list of procedures designed to confront what was then identified as a 'triple threat' to the continuity and 'authenticity' of music and performing arts, namely, the "rivalry of the new entertainments, in particular those dispensed by the mass media; the rapidity of social and cultural evolution; the ever-increasing influence of alien factors" (Ten-year Plan, Intro, Para.13).

The preservation and promotion measures, initially advocated for Africa and Asia, followed later by Latin America, included: identifying the individuals and groups practicing 'folk arts and skills' (ibid: Intro, Para. 4) on these continents and encouraging the continuation of their practices; researching, documenting and increasing the circulation of productions; promoting festivals as a form of stimulating exchange between groups; the creation of official performance groups; finally, an endless number of measures of apparently questionable viability and effectiveness, given the complex realities that were and still are found on these continents.

Despite the proviso made by the signatories to the effect that contemporary "creations in traditional style" and "authentic African and Asian creations which borrow forms and means from other cultures" (ibid: Item II, 1.d) should not be discouraged, the guide to drafting the 'Ten-year Plan' proposes a wide-ranging and herculean effort to avoid changes already made and irreversible in a world in? transformation. However, the institution's assessment of these safeguarding measures was apparently positive, as declared in the official report:

\footnotetext{
14 Among the precursory initiatives we can highlight Japan: Law for the Protection of Cultural Properties, 1950; Brazil: National Folklore Commission, 1947; Campaign to Protect Brazilian Folklore, 1951; Federal Decree 3551, 200o; Bolivia: Supreme Decree 08396, 1968, for the protection of folkloric music produced by native groups; Supreme Decree 12626, 1977, for the protection, promotion and safeguarding of the country's folkloric expressions that form part of Traditional Culture. Mexico: National Museum of Popular Cultures, 1982.

15 Reinforcing and complementing footnote 1, I emphasize that when referring to documental sources I seek to maintain the original vocabulary wherever possible, highlighting in italics and between quote marks, and contextualizing it whenever necessary. The citations will follow the format adopted by this edition.

16 UNESCO Document IGC/XII/12. Paris, 1 October 1973.

17 The meeting of experts was based on Recommendation No.3 of the Final Report of the Intergovernmental Conference on Cultural Policies in Asia," $10-20$ December 1973; and No. 12 of the Final Report of the Intergovernmental Conference on Cultural Policies in Africa," 27 October - 6 November 1975.
} 
"The success of UNESCO's programme on African national languages in 1960 and 1970 s is well known to the world." As evidence, the report cites the efforts "to settle the problems of transcription, spelling, grammar and dictionaries of more than 70 African languages on the basis of recorded oral traditions. ${ }^{{ }_{18}}$ Mention is also made of the production of more than 150 LPs and seventy compact discs and cassettes, some of which had already been used to 'revitalize' musical pieces that no longer existed, as well as the organization of regional festivals in Africa, Latin America, the Caribbean and the South Pacific, which 'have done much to enhance the revalorization of the traditional cultures. ${ }^{19}$

I cite the Ten-year plan since it registered the need expressed at the time - not coincidentally, by emergent nation $s^{20}$ - for legal protection of cultural products circulating in an incipient international market and indicates the scale of the shift taken by heritage policy in the run-up to the World Conference on Cultural Policies, held in Mexico City in 1982.

\section{Democracy, development and identity}

The Mexico City Declaration on Cultural Policies (hereafter Mondiacult) enunciated a set of theses based on a conception of cultural preservation fairly compatible with the ideals and methods of the ICH Convention. But what is 'safeguarding' in the context of Mondiacult, and to what does it refer?

From the outset, it is important to note that this treaty leaves out the concept folklore and the adjective popular then in vogue and, furthermore, diverges from these concepts by proposing a definition of culture not limited to the simple listing of domains of social life. ${ }^{21}$ On the contrary, the Mondiacult declaration attributes meanings and generates some important implications by announcing that culture "includes not only the arts and letters, but also modes of life, the fundamental rights of the human being, value systems, traditions and beliefs" and that "it is culture that gives man the ability to reflect upon himself." "22

New elements and important perspectives are introduced into the debate - with regard not only to safeguarding, but cultural policies in general - by adopting identity, democracy, respect for diversity and social responsibility as key reference points. Here, preservation is undertaken against "damage or destruction" and "urbanization, industrialization and technological penetration," as had also been the aim, to some extent, in preceding instruments, but also against "illicit trafficking," "colonialism, armed conflict, foreign occupation and imposition of alien values" (Item 25). On this last aspect, the Mondiacult declaration responds to contemporary concerns to include in the "principles that should govern cultural policies," the viewpoint that the culture industry and the advance of technology "often disregard the traditional values of society and kindle hopes and aspirations which are not in keeping with actual needs of its development," compounding by the fact that "the absence of national cultural industries may, particularly in developing countries, constitute a source of cultural dependence and give rise to alienation" (Item 38 ).

Specifically, in the field of heritage, the Mondiacult treaty innovates by associating preservation with motives and meanings different to those that guided previous instruments, exposing their limitations and lending support to demands to readjust them. In other words, by acknowledging the dynamic reality of culture and, at the same time, the power imbalance existing between local agents (principally in developing countries) and the culture industry - especially at international level- the new treaty created the logical and political

\footnotetext{
18 Report of the International Expert Meeting for the Safeguarding and Promotion of the Intangible Cultural Heritage of Minority Groups in Vietnam, Hanoi, 15-18 March 1994. Annex VIII, p. 6. (GN).

19 Ibid.

20 Significantly, in 1955 the Asia-Africa Conference had taken place in Bandung, Indonesia, referred to by Sukarno, then President of the country as "the first intercontinental conference of colored peoples in the history of mankind" (cited in Tsing 2005: 83).

21 See Edward Tylor's (1832-1917) definition of culture as "that complex whole which includes knowledge, belief, art, morals, law, custom, and any other capabilities and habits acquired by man as a member of society" (1958: 1).

22 Mondiacult, Preamble.
} 
framework for proposing actions designed to promote this dynamic and rebalance the forces in this field, abandoning the impossible mission to freeze change. Moreover, by associating heritage with ways of life and with 'harmoniously balanced' development (today one would say 'sustainable'), this treaty situates preservation at the level of social policies, affirming the right of communities to protect their heritage and their corresponding responsibility (Mondiacult, Para. 24) to respect the rights of others.

"Culture," the declaration states, "is the essential condition for genuine development" (ibid: Para. 41). "Cultural identity," it continues, "is a treasure that vitalizes mankind's possibilities of self-fulfilment by moving every people and every group to seek nurture in its past, to welcome contributions from outside that are compatible with its own characteristics and so to continue the process of its own creation" (ibid: Para. 3).

Responding to this task, UNESCO acquires a position of "capital importance" (ibid: Para. 52) "to further the development of mankind" and the "establishment of a lasting peace" (ibid: Para. 51), objectives to be attained by an overall development of society that "calls for complementary policies in the fields of culture, education, science and communication with a view to the establishment of a harmonious balance between technological progress and the intellectual and moral advancement of mankind" (ibid: Para. 30). In the heritage area, the verbs describing the stances taken by nations in response to these threats are "preserve and appreciate," "defend sovereignty and independence," "affirm and promote," "restitute" (ibid: Paras. 24, 25, 26). We can observe a conception of emergent States and social entities as proactive agents operating in a world in transformation. As a metacultural construction, heritage acquires creative force, impetus and movement that resituates it vis-à-vis demands for copyright protection. Moving beyond the culturally produced objects themselves, attention is already being paid to the conditions under which they are produced.

\section{A lesson of folkways documentation}

The Recommendation on the Safeguarding of Traditional Culture and Folklore ${ }^{23}$ (hereafter the 1989 Recommendation), cited in the Preamble to the ICH Convention, merits closer scrutiny. As implied by its title, the object of this treaty is "folklore (or traditional popular culture)" as in previous documents, defined as "the totality of tradition-based creations of a cultural community, expressed by a group or individuals and recognized as reflecting the expectations of a community in so far as they reflect their cultural and social identity" (1989 Recommendation, Para. A).

To these ends, the treaty in question provides a detailed description of the measures to be taken to identify, conserve, preserve, disseminate and protect folklore. The detailed descriptions of the actions encompassed by these diverse rubrics - which, indeed, are repeated over the course of the process analysed here - provides a clearer insight into the future imagined by its drafters and signatories. In principle, the treaty follows the direct line of the Ten-Year Plan mentioned earlier in referring specifically to "tradition-based creations of a cultural community" (ibid: Para. A). However, they differ in one very important aspect, which relates to the articulation of these cultural creations with the social context in which they occur, whether practiced or registered in traditional settings, or showcased and made available by the market of cultural goods, "as an integral part of cultural heritage and living culture" (ibid: Considerandum 3). It is important to consider the consequences of this change of conception for the purposes of implementing the actions advocated in the document. Some of its dispositifs provide important clues and suggest additions to the general comments presented previously, in the sense of identifying the specific outlook of this instrument. 
In terms of identification, the treaty recommends "national inventories of institutions concerned with folklore" (my underlining) associated with updating "regional and global registers." It also proposes the creation of "identification and recording systems (...) in view of the need to co-ordinate the classification systems used by different institutions" as well as "stimulate the creation of a standard typology" (ibid: Para. B, a - c).

Conservation refers to documentation and its use by "researchers and tradition-bearers." On this point, the 1989 Declaration includes the significant proviso that "while living folklore, owing to its evolving character, cannot always be directly protected, folklore that has been fixed in a tangible form should be effectively protected." Specifically, it proposes to establish national archives, "a central national archive function for service purposes" and museums or folklore sections at existing ones, which "emphasize the living or past aspects of [popular] cultures." It also recommends harmonizing collection and archival methods, training specialized personnel and providing the means to "securing the cultural community an access to the material" (ibid: Para. C, a - g).

On the question of preservation, Member States, for the "protection of folk traditions and those who are the transmitters" against "the impact of the industrialized culture purveyed by the mass media," should disseminate folklore through "formal and out-of-school curricula," "guarantee the right of access of various cultural communities to their own folklore," set up "inter-disciplinary national coordinating bodies," "provide moral and economic support for individuals and institutions studying, making known, cultivating or holding items offolklore" and promote scientific research on these topics (ibid: Para. D, a - e).

The next aspect is promotion. The Declaration proposes "a fair dissemination" of folklore, stating that "distortion during dissemination should be avoided so that the integrity of the traditions can be safeguarded." The instruments to achieve this end are organization of events, better coverage by the media, full-time jobs to folklorists, production of educational materials, ensuring the availability of adequate information, promotion of national and international exchanges between people and institutions, and a commitment to "encourage the international scientific community to adopt a code of ethics ensuring a proper approach to and respect for traditional cultures" (ibid: Para. E, a - g).

In relation to (legal) protection of this heritage, it can be observed that the 1989 Declaration Para. F conceives heritage as "manifestations of intellectual creativity whether it be individual or collective" and, as such, "must be safeguarded by and for the group (...) whose identity it expresses" (ibid: Para. B, my underlining). Individuals and groups "express" (ibid: Para. A) and 'transmit' (ibid: Paras. D and F.b.i) their collective creations. The treaty thus enunciates the conditions under which these individuals and groups become people with rights, affirming, in the 1989 Declaration Para. F, that folklore "deserves to be protected in a manner inspired by the protection provided for intellectual productions" (my underlining). The caution observed in the latter text is justified since although "there are various categories of rights which are already protected and should continue to enjoy protection in the future" (ibid), the 1989 Declaration draws the attention of "relevant authorities" to the need to create instruments that protect diverse 'intellectual property aspects" [ibid: Paras. $\mathrm{F}(\mathrm{a}) ; \mathrm{F}(\mathrm{b})$ ], both in the interests of local agents and in those of "the collector" of folklore and "the archives."

It is worth observing that this recognition of the limitations of the legal instruments protecting folklore then in force, inherently national in scope, ${ }^{24}$ also applies to the work developed by UNESCO and WIPO: according to the 1989 Declaration, "this work relates to only one aspect of folklore protection [intellectual property rights] and that the need for separate action in a range of areas to safeguard folklore is urgent" (ibid: Para. F.a). At the time - and even today in diverse sectors of ICH, such as, for example, craft and popular art - legislation did not sufficiently or adequately consider the collective nature of these intellectual creations, nor the role of individual agents or even concrete groups in their transmission and creative reproduction. In the context of safeguarding ICH, this area of rights remains a topic of debate still today. Indeed UNESCO's 2001 Secretariat Report concluded that

24 See note 23 
"recent meetings (the World Forum on the Protection of Folklore organized by UNESCO and WIPO in Phuket (Thailand) in 1997, followed by four regional meetings in 1999), came to the conclusion that intellectual property does not give appropriate protection to expressions of folklore and a sui generis regime specific to this purpose needs to be developed." 25

Given both the detailed nature of the declarations, presented here in summarized form, and its standardizing and somewhat centralizing aim in terms of institutional structures and some of the advocated methods, this legal instrument clearly exemplifies what, in my opening remarks, I called a dispositif. The 1989 Declaration leaves a legacy, undoubtedly, as the enunciation of a basic agenda of what we today call 'safeguarding' and that, in this treaty, are largely subsumed by the idea of 'preservation' still, a generic term then adopted in relation to diverse types of heritage. But as an instrument for generating and orienting effective policies, it would be difficult to apply in a world as politically diverse and controversial, and as economically unequal, as our own. Not by chance, what was intended as a legally binding instrument became merely a declaratory statement.

\section{Convergence in Hanoi}

The paths to safeguarding begun in the discussions on folklore and popular culture in Africa and Asia, and the guidelines established for cultural policies in Mondiacult, converged at the expert meeting held in Hanoi, 1994, in response to changes in the global political and economic setting. ${ }^{26}$

Although this meeting was designed to address national questions pertaining specifically to Vietnam, it included a number of aspects involved in the construction of safeguarding as a heritage policy instrument that are worth exploring here. In the opening speech of the meeting, referring to emerging countries in general, the Director of the Division of Arts and Cultural Life, representing UNESCO's Director General, declared that:

in the wake of sudden transformation of the world political and cultural situation, newly emerged states and groups in search of their own identity began to look closely at the situation of the safeguarding and promotion of their traditional heritages. UNESCO felt the urgent necessity to readapt its cultural policy to the new situation of the world. ${ }^{27}$

In support of this work, he presented four priorities, endorsed by the international conferences, held in 1993, which established new guidelines for intangible cultural heritage programs: (1) "the urgent need (...) to recognize the value of the traditional cultures which merits great respect and the vital need for their preservation and transmission"; (2) "revitalization of the intangible cultural heritage," considering that "culture is in a constant state offlux" and that "revitalization of traditional cultures should not necessarily mean reviving old cultures as they used to be"; (3) "the need to safeguard the heritage which are threatened with disappearance"; and (4) "some intangible heritages constitute the basic factor for the attainment of sustainable human development." ${ }^{28}$

We can straight away highlight use of the expression 'intangible cultural heritage' to designate the object of these policies, a theme that had occupied UNESCO's attention since at least 1984, when it convoked a meeting of experts to define what was then called "non-physical heritage." ${ }^{29}$ Moreover, important elements of safeguarding had already been announced, anticipating their institution in 2003: these included the priority given to the subcategory then designated "heritage threatened with disappearance," a more flexible approach to the relationship between heritage and tradition following acceptance of the principle of "readaptation to the modern

\footnotetext{
25 UNESCO 161 EX/15. Report on the Preliminary Study on the Advisability of Regulating Internationally, Through a New Standard-setting Instrument, the Protection of Traditional Culture and Folklore, by Janeth Blake, 2001. Para.13.

26 Expert Meeting for the Safeguarding and Promotion of the Intangible Cultural Heritage of Minority Groups in Vietnam, held in Hanoi, 15-18 March 1994.

27 Report of the International Expert Meeting for the Safeguarding and Promotion of the Intangible Cultural Heritage of Minority Groups in Vietnam,

held in Hanoi, 15-18 March 1994. Annex VIII, p. 6.

28 Ibid, pp. 7-8.

29 UNESCO. Consultation of experts to define the non-physical heritage. Paris, 27-30 November 1984. CLT 84/Conf. 603.
} 
world," ${ }^{\circ}$ and attention to the connections between heritage preservation and sustainable human development. At this point, we can observe that the meanings of safeguarding had reached a level where change no longer necessarily posed a threat, nor preservation simply the saving or rescuing of fragments of a vanishing world.

\section{Intangible masterpieces ${ }^{31}$}

The Proclamation of the Masterpieces of the Oral and Intangible Heritage of Humanity (hereafter Masterpieces Program) was issued in 1997. It referred to the general guidelines of the 1989 Declaration and, according to the "Regulations relating to the proclamation by UNESCO of masterpieces of the oral and intangible heritage of humanity" (Item 1, a), aimed "to pay tribute to outstanding masterpieces of oral and intangible heritage of humanity" as well as "to outstanding masterpieces of the oral and tangible heritage of humanity, which would be cultural spaces or forms of popular or traditional cultural expression and which would be proclaimed masterpieces of the oral and intangible heritage of humanity." ${ }_{32}$

This somewhat eccentric formulation suggests the institution's endeavour to create a standard setting instrument of actions based on regimes founded on very different, not to say mutually incompatible, conceptual bases in terms of objects and the notion of value. On one hand, it foregrounded a type of object that, for the specialists, no longer fitted into the straightjacket of the conventional notion of folklore and celebrated the singularity of cultural expressions. On the other hand, it adopted a principle of value that was necessarily comparative (present in the idea of the masterpiece) and universalist in inspiration (outstanding universal value), ingrained in institutional practices and in the public opinion established by the Convention Concerning the Protection of the World Cultural and Natural Heritage, adopted in 1972 (hereafter the 1972 Convention).

The requirement of exceptionality established for candidacies to this program - a requirement itself difficult to identify and measure - proved inadequate in the case of ICH, according to UNESCO's own assessment, since it presumed an undesirable hierarchy between cultural elements and potentially stimulated competition between social groups, if not nations, and did not encourage the desired peace and mutual understanding between peoples.

It is notable that, for practical purposes, the words 'masterpiece, 'exceptionality' and 'uniqueness,' despite later being abolished from the language of the UNESCO/ICH regime, is sometimes employed by States Parties, and indeed by local stakeholders, when referring to the presence of their cultural elements on the Representative List created by the ICH Convention. This shift from the 'everyday' to the 'exceptional,' so to speak, also suggests that the amplification of the symbolic effects along the lines stimulated by the Masterpieces Program - undesired by the 'founding fathers and mothers' of the UNESCO/ICH regime - is strongly echoed and appropriated at a popular level. In terms of safeguarding, aesthetization is a significant undesired effect that must be mitigated.

Safeguarding, in the Masterpieces Program as in the 1989 Recommendation, which sets out its technical parameters, ${ }^{33}$ implies identification and inventorying; research and documentation; enhancing the transmission to younger generations; awareness raising; legal protective measures; and dissemination through specialized curricula in schools and universities. Diverging from the latter, the Program does not address questions relating to the 'revitalization' of those cultural elements at risk. Its main practical contribution to the establishment of a new heritage policy has been to raise awareness of the public and of Member States concerning the symbolic 
potential of this heritage for the promotion of cultural diversity and for the international visibility of countries and ethnic groups around the world. In this way, the Program planted seeds that would be harvested in the implementation of the 2003 Convention, especially in its ratification by the Member States.

\section{From appreciation of folklore to empowerment of living cultures}

The need to create a new binding instrument to protect what had already been enshrined as intangible cultural heritage' would become widely debated over the 199os and culminated in the preparation of the Preliminary Study on the Advisability of Regulating Internationally, Through a New Standard-setting Instrument, the Protection of Traditional Culture and Folklore, by Janet Blake (2001), a document that ended up referencing the next stages of the process being analysed here.

Prior to its assessment and acceptance by UNESCO's General Assembly, the study was examined at an expert meeting in the city of Turin (Italy), which issued a favourable opinion and approved an Action Plan (hereafter the Turin Action Plan). Some points are worth highlighting in relation to safeguarding. ${ }^{34}$ It is immediately evident that the proposal was inspired at a technical level by the 1989 Recommendation, though it diverges from the latter on some crucial points, including the following:

1. It considers use of the concept of folklore inappropriate and urges UNESCO to "use the terminology and working definitions" proposed in the Turin Action Plan (Para. 6);

2. Furthermore, it understands this to encompass artistic products "but also the knowledge and values enabling their production, the creative processes that bring these products into existence, and the modes of interaction by which these products are appropriately received and appreciatively acknowledged" (Turin Action Plan, Paras. 7 and 9), which signals an extremely important shift of focus in safeguarding practices from the objects themselves to the processes involved in their production;

3. It reinforces the agency of "creators, audiences, NGOs and various actors of the private sector" (ibid: Para. 8), affirming that 'the grass-roots practitioners, creators and their communities (...) should be recognized as primary agents in the formulation of cultural policy" (ibid: Para. 10) and that safeguarding must "be conducted by the creators and practitioners so that they will continue to fully enjoy freedom of creation, expression and transmission of their cultures" (ibid: Para 13);

4. It recognizes that the meaning of safeguarding "must be founded on universally accepted human rights, equity and sustainability and on respect for all cultures that respect other cultures" (ibid: Para.12, a) and points to various consequences of this principle (ibid: Para 11);

5. It suggests that safeguarding is not a defensive strategy but requires "creativity and enactment by the agents of the communities that produce and maintain it" (ibid: Para.12, b) and, therefore, "should facilitate, encourage and protect" their right and capacity to develop "their own approaches to manage and sustain it" (ibid: Para.12, c),

6. And finally, in relation to action methods, instead of detailing the constitutive elements of an ideal and normative approach, as was done previously, the Action Plan adopts a stance that privileges the capacity to formulate solutions to specific problems by proposing that the States Parties "encourage, disseminate and proclaim best practices" (ibid: Para.14). 


\section{By way of conclusion}

The proposals of the Turin Action Plan apropos safeguarding were largely incorporated by the ICH Convention, creating significant possibilities for the development of a democratic heritage policy as sui generis as its object. As we have seen, though, the process was far from unilinear and finalist. Accompanying the debates of the cultural policies of its time, it manifests a back history of ideological and political disputes, which reflect structural problems endemic to the sociopolitical contexts typical of their object in all its diversity. Notably, the theoretical impasses and methodological challenges within the field of cultural preservation did not have the same importance as questions relating to the meaning and objectives of preservation. Indeed, the safeguarding measures adopted in Article 2(3) of the Convention ${ }^{35}$ never left the stage throughout the period. The disputes concerned the objectives that these procedures should serve and the strategies that should guide these procedures in order for them to attain this aim, subsumed to the idea that "[s]afeguarding means measures aimed at ensuring the viability of the intangible cultural heritage." ${ }^{36}$

Not by chance, the first public administration instruments to focus on manifestations of cultural diversity at national and international level were the initiatives of Third World countries or created vis-à-vis objects located in Africa, Southeast Asia and Latin America. One of the reasons can be traced to the fact that, in these same countries, until this period ethnic diversity was - and to a large extent still is - strongly associated with the lack of equity in terms of access to material resources and citizenship rights, in particular that of manifesting and celebrating identities different from the dominant. At least from the view point of these regions, the specific sense of the process studied here - and, perhaps, the reason why a large number of emergent countries readily supported to the Convention as States Parties or States Non-Parties - is related to the tension between the ruling elites and the indigenous popular heritage communities, mediated by mechanisms for (re)constructing hegemonies. ${ }^{37}$

Obviously, this framework is not valid everywhere worldwide and also varies in time, according to the political and economic (trans)formations of each country. Numerous exceptions can be listed. Nonetheless, this, I think, is the dominant situation on various continents and, when the reality diverges from this pattern, 'public administration' is frequently based on vestiges of elitist and authoritarian political institutions and cultures, which also tend to be male-oriented. Not coincidentally, the objectives of the heritage regimes outlined here were, for a long time, to collect artefacts and register supposedly 'pure' and 'authentic' manifestations of the culture of populations whose extinction was seen as inexorable. Alternatively, the aim was to eternalize testimonies to human ingenuity in its supposedly maximum splendour and placing them in the pantheon of the 'masterpieces of humanity'. The underlying notion is the same in both cases: heritage is seen as collections of reified entities, dissociated from the social bases and circumstances that created them.

The critique and resistance to the use of the concept of folklore in Latin America, where the adjectives 'indigenous' and 'popular' are preferred (most often used in the plural), is, precisely, an outcome of this antagonism, explicit or latent, between the interests of administrative institutions and those of the population. In this region, one of the main uses of the ICH Convention derives from its potential to mitigate historically established inequalities. Perhaps in some African regions the priorities are other and sometimes seem to relate to ethnic and national border conflicts or alliances. In countries that were once behind the Iron Curtain, some priorities seem to be to liberate popular cultural expressions from institutions where they were confined

\footnotetext{
35 Article 2(3) mentions the following measures: identification, documentation, research, preservation, protection, promotion, enhancement, transmission and revitalization.

36 Ibid., my emphasis.

37 On this problematic, especially the conception of 'cultural communities,' see the collection edited by Nicholas Adell, Regina Bendix, Chiara Bortolotto and Markus Tauschek (2015).
} 
for a long time. The possible reasons are multiple, and I have no wish to speculate on them. But diverse clues appear to corroborate the hypothesis that the metaculture produced by heritage regimes, in the case of what we today denominate $\mathrm{ICH}$, is perceived and administered as a dispositif of power.

The trajectory delineated here - which is an open process, given that the Convention's implementation poses successive new challenges to its managers - seems to suggest a series of advances and setbacks to social empowerment. If so, then, in our feedback - as researchers, activists or agents - it remains for us to strengthen, diversify and modulate our channels of communication to be able to hear more clearly and respond more promptly to the voices manifested all about us.

Translated by David Rodgers

Received: November 21, 2018

Approved: January 22, 2019

* The two papers published in the present volume stem from a stimulating invitation made by Janeth Blake (Associate Professor of Law at Sahid Beheshti University, Tehran, Iran), a valued partner in intangible cultural heritage debates since the early days of the ICH Convention, and Lucas Lixinsky (Associate Professor at the Law School, University of New South Wales, Sydney, Australia), who also provided me with access to a rich collection of documents essential to their preparation. I wish to thank them both for the opportunity they gave me to comment on one of the key issues of the treaty, as well as for their wise comments on preliminary versions of these texts.

\section{References}

ADELL, Nicholas; BENDIX, Regina; BORTOLOTTO, Chiara and TAUSCHEK, Markus (eds.) 2015. Between Imagined Communities and Communities of Practice. Göttingen: University of Göttingen Press. Available at http://resolver.sub.uni-goettingen.de/purl?univerlag-isbn-978-3-86395-205-1

APPADURAI, Arjun (ed.). 1986. The social life of things. Cambridge: Cambridge University Press.

ARANTES, Antonio. 2009. "Heritage as Culture: Limits, Uses and Implications of Intangible Cultural Heritage Inventories". In: Toshiyuki Kono (ed.), Intangible Cultural Heritage and Intellectual Property. Communities, Cultural Diversity and Sustainable Development. Antwerp: Intersentia. pp. 51-75.

BENDIX, Regina F.; EGGERT, Aditya; PESELMANN, Arnika (eds.). 2012. "Heritage Regimes and the State". Göttingen Studies in Cultural Property, 6. Universitätverlag Göttingen. Source: http://webdoc.sub.gwdg.de/ univerlag/2012/GSCP6_Bendix.pdf. Accessed: 30 January 2018.

DAVALON, Jean. 2015. "Memória e patrimônio: por uma abordagem dos regimes de patrimonialização". In: Cécile Tardy, Vera Dodebei (eds.), Memória e novos patrimônios Open Edition Press. Source: http://books. openedition.org/oep/866. Accessed: 23 January 2018. 
FOUCAULT, Michel. 1977. “Le jeu de Michel Foucault” (Entretien avec D. Colas, A. Grosrichard, G. Le Gaufey, J. Livi, G. Miller, J. Miller, J.-A. Miller, C. Millot, G. Wajeman). Ornicar? Bulletin Périodique du Champ Freudien. Source: http://1ibertaire.free.fr/MFoucault158.html. Accessed: 31 October 2017.

HARVEY, David. 2001. "Heritage pasts and heritage presents: temporality, meaning and the scope of heritage studies". International Journal of Heritage Studies, 7(4): 319-338.

JAKOBSON, Roman. 1963. "Linguistique et poétique". Essais de linguistique générale. $2^{\text {nd }}$ edition. Paris: Les Éditions de Minuit. pp. 217-218.

KIRCHENBLATT-GINBLETT, Barbara. 2004. “Intangible Heritage as Metacultural Production”. Museum International, $56(1-2): 52-65$.

SMITH, Laurajane. 2006. Uses of heritage. New York: Routledge.

TSING, Anna. 2005. Friction. Princeton/ Oxford: Princeton University Press.

TYLOR, Edward. 1958 [1871]. Primitive Culture. New York: Harper.

WAGNER, Roy. 1975. The invention of culture. Chicago and London: The University of Chicago Press

\section{Antonio Arantes}

State University of Campinas, Department of Anthropology, Campinas/SP, Brazil

Author's email: arantes1@unicamp.br

http://orcid.org/0000-0002-2463-680X 


\section{Errata}

In Volume 16, of Vibrant: Virtual Brazilian Anthropology, published in February 2019, in the section "Articles", the article by Antonio Arantes, 'Safeguarding', a key dispositif of the ICH convention, with DOI number: http://dx.doi.org/10.1590/1809-43412019v16a201, was published in the wrong section. This article is part of the dossier Safeguarding, its Genealogy and Governance. Two Essays on UNESCO's Convention for the Safeguarding of Intangible Cultural Heritage:

For:

Article

Read:

Dossier Safeguarding, its Genealogy and Governance. Two Essays on UNESCO's Convention for the Safeguarding of Intangible Cultural Heritage

In Volume 16, of Vibrant: Virtual Brazilian Anthropology, published in February 2019, in the section "Dossier Safeguarding, its Genealogy and Governance. Two Essays on UNESCO's Convention for the Safeguarding of Intangible Cultural Heritage", the article of Antonio Arantes with DOI http://dx.doi.org/10.1590/180943412019v16a201 had their titles changed.

In English:

For

'Safeguarding', a key dispositif of the ICH convention

Read

Safeguarding. A key dispositif of UNESCO's Convention for the Safeguarding of Intangible Cultural Heritage

In Portuguese:

For

‘Salvaguarda', um dispositivo-chave da Convenção do Patrimônio Imaterial

Read

Salvaguarda. Um dispositivo-chave da Convenção da UNESCO para a Salvaguarda do Patrimônio Cultural Intangível 